\title{
Point-of-care stem cell therapy (pocst): multisite transplantation of autologous bone marrow-derived mononuclear cells in 85 patients with amyotrophic lateral sclerosis improves survival
}

\begin{abstract}
Background: Amyotrophic lateral sclerosis (ALS) is a fatal disease characterized by a progressive degeneration of motoneurons in the brain and in the spinal cord. There is no cure for ALS and the current available treatments are mostly directed to maintain the quality of life by a multidisciplinary palliative approach. Several stem cell therapies (SCT) have been proven to have beneficial influence on all affected neural tissues which are inflicted with motor neurons degeneration.
\end{abstract}

Objective: Our principal aim was to investigate the safety and effectiveness of the Point-of-Care Stem Cell Therapy (POCST).

Methods: The study was a retrospective study from 85 patients with ALS treated as unproven intervention in the clinical practice with autologous bone marrow-derived mononuclear cells (BM-MNCs). The primary endpoint was to establish the safety profile of the intervention. The secondary endpoint was to evaluate the effects on functional impairment (ALSFRS-R), survival and its relationship with bone marrow (BM) content, number of SCs in BM, number and characteristics of stem cells (SCs) infused (CD34+, vitality and concentration factors) and routes of infusion.

Results: No patient presented major side effects. $52.6 \%$ of the patients maintained the ALSFRS-R score in a mean follow-up of 7 months. Comparing our patients to the population based study that has the highest survival rates from the moment of diagnosis, we observed that our patients had a mean increased in survival rates of $21.8 \%$ in the first year, $41,6 \%$ in 5 years and $45.2 \%$ in 10 years. We follow the patients just after the POCST however with retrospective assessment of patient's medical history we were able to assess survival rates from the moment of the diagnosis and up to 10 years. More ml. available in BM conferee higher amounts of CD34+ cells and vitality per $\mathrm{ml}$. The patients with more than $80 \%$ vitality in the BM samples, more than 4 million CD34+ cells infused Intramuscular (IM) and higher amounts of CD34+ cells infused IV had statistically significant better clinical outcome and survival. We also found that the sub-occipital (SOP) infusion could add better response to the treatment alone or combined with lumbar puncture infusion improving the survival.

Conclusion: POCST is a safe method that reduces progression and improves the survival compared to any other treatment or combination of them. The CD34+ and vitality as well as the IM route of infusion are related to better outcomes. To the best of our knowledge this is the first study with such a large sample and with a follow-up more than a year for patients with ALS treated with autologous BM-MNCs.

Keywords: amyotrophic lateral sclerosis, motoneuron disease, stem cell therapies, alsfrs-r
Volume 2 Issue 3 - 2017

Francisco Ruiz-Navarro,' Georg Kobinia ${ }^{2}$

'Austrian Society for Regenerative Medicine,Austria ${ }^{2} \mathrm{SCT}$, Austria

Correspondence: Francisco Ruiz-Navarro, Austrian Society for Regenerative Medicine, Wollzeile 3 Top 2.I 1010 Vienna, Austria, Email ruiznavarro.md@gmail.com

Received: February 13, 2017 | Published: March 27, 2017

\section{Introduction}

\section{Current knowledge}

Amyotrophic lateral sclerosis (ALS) is a fatal disease characterized by a progressive degeneration of motoneurons in the brain and in the spinal cord. ${ }^{1}$ The incidence range from 1.2 to 4 per 100,000 personyears in Caucasians. ${ }^{2}$ In the European population is 2.6 per 100,000 person-years. ${ }^{3}$ It is higher among men with a peak in the eight decade of live. ${ }^{3}$
The known risk factors include certain genetic polymorphisms, age and gender. ${ }^{4,5}$ Recent studies suggest that genetic and environmental mechanisms together are a feasible explanation for the pathogenesis, however the etiologies are still undiscovered for the majority of patients. ${ }^{6}$

The clinical presentation is a consequence of a progressive muscle weakness that leads to death generally from a respiratory failure. ${ }^{2}$ The clinical findings include signs and symptoms of upper and lower motoneuron disease along with emotional lability. ${ }^{2}$ 
There is no cure for ALS and the current available treatments are mostly directed to maintain the quality of life by a multidisciplinary palliative approach. ${ }^{2}$ Riluzole is the only pharmacologic treatment that is accepted as a disease modifier; nevertheless since its introduction in the early 90 's the real effect has been controversial. It is recommended just for use in early stage of the disease, however clinicians advocate its use in any stage because lack of other options.

The outcome after different treatments or the combination of them varies from one study to another probably because the use of different outcome measurements. ${ }^{7}$ ALS can mimic a plethora of neurological and orthopedic diseases and hence the beginning of the disease and the length of duration are arbitrary numbers. Today, it is accepted that the primary measure that better predicts the effect of a treatment is the survival rates. ${ }^{8}$ The survival rates vary from months to decades usually less than 2 to 3 years since the first symptoms. ${ }^{9}$ While some research groups report some survival improvement, other populationbased studies documented an unexpected decline in it regardless of the treatment. ${ }^{10-20}$ The factors that are thought to contribute to a better survival are: limb-onset, youth, better motor function, better respiratory status, stable weight, longer interval between appearing of symptoms and diagnosis, inter alia. ${ }^{21}$ The therapeutic interventions including Riluzole combined with other measurements including tracheotomy infer modestly on the survival. ${ }^{22}$ The symptomatic interventions (percutaneous gastrostomy, mechanical ventilation, tracheostomy and comprehensive care) are the ones specially claimed to be responsible for prolonged survival rates, ${ }^{21,23,24}$ even they are not related to the disease process itself.

The disturbingly increasing incidence in recent years, ${ }^{25}$ the inconclusive pathogenesis for more than 100 years $^{26}$ and the absence of an effective treatment make imminent the active search for new treatment options, understanding and cure of ALS.

\section{Stem cell therapy and ALS}

Since the first report of human stem cells (SCs) more than 15 years ago $^{27}$ their use has been a mayor field of research for different diseases including ALS. The first animal model described by Appel et al., ${ }^{28}$ proved that bone marrow-derived mononuclear cells (BM$\mathrm{MNCs}$ ) and umbilical cord-derived mononuclear cells (UC-MNCs) are able to migrate to the central nervous system $(\mathrm{CNS})^{28}$ and produce neuroregeneration. ${ }^{29}$ Neuroprotection probably occurs through the regulation of the immune system and the inflammatory response. ${ }^{30}$ Later, several groups reproduced these findings, describing also paracrine mechanisms of immunomodulation occurring through secretomes, substances that are released when mononuclear cells die. ${ }^{31-33}$ This change of paradigm is modifying our understanding of regenerative therapies for neurological disease.

ALS has many types of cells involved in its pathogenesis. The main affection is well-known to be over motoneurons, ${ }^{2}$ however there is also involvement of other types of neurons, ${ }^{34}$ non-neuronal cells (astrocytes ${ }^{35}$ and microglia ${ }^{36,37}$ and the surrounding environment. ${ }^{38-40}$ The Stem cell therapies (SCT) has proven beneficial influence in all affected neural tissues leading to motoneurons regeneration, ${ }^{41-44}$ astrocytes replacement that slows motoneuron loss with a consequent survival increase, ${ }^{45}$ microglia regeneration ${ }^{46,47}$ and growth factors secretion that promotes maintenance of motoneurons. ${ }^{48,49}$ The effects seemed to be greater when the SCs delivery is intrathecal (IT) ${ }^{50}$ or intramuscular (IM). ${ }^{51}$
The infusion of IT BM-MNCs in pre-clinical studies, pilot studies and phase I clinical trials has proven to be safe without promoting tumor formation or structural deformations in a short and follow-up, with shallow presence of minor side effects. ${ }^{52,53}$ There are several ongoing phase I and II clinical trials using different sources of SCs achieving also safe profile and therapeutic effectiveness. ${ }^{54}$

\section{Objective}

Our principal aim was to prove the safety and effectiveness of the Point-Of-Care Stem Cell Therapy (POCST) with an open label pilot study under the condition of "Unproven intervention in Clinical Practice" described in the Ethical Principles for Medical Research Involving Human Subjects of the World Medical Association of Helsinki Declaration. ${ }^{55}$

\section{Method}

\section{Study design}

The study is an open label pilot study in 85 patients with ALS, carried-out from August 2011 to December 2013. The primary endpoint was to document adverse effects and establish the safety profile of the intervention within a short and long-term period (from 1 to 45 months). The secondary endpoint was to evaluate the effects of POCST on functional impairment and survival and its relationship with bone marrow (BM) content, number of SCs in BM, number of SCs infused and routes of infusion.

\section{Patient selection}

Patient selection was based on the World Medical Association Helsinki Declaration about ethical principles for medical research involving human subjects. ${ }^{55}$ All the patients were men and women between 20 and 80 years old (y/o) with definite diagnosis of ALS established in accordance to El Escorial revised criteria of the World Federation of Neurology, ${ }^{56}$ including bulbar and limb onset indiscriminately. The exclusion criteria include substantial lesions on imaging studies that explain the symptoms, signs of dementia, other incapacitating or life-threatening diseases, use of ventilator, hepatic or renal dysfunction and pregnancy.

\section{Pre-procedure assessment}

First, a written informed consent was obtained from the patients or their legal guardian. Afterwards, an initial evaluation was made by their current treating neurologist and includes confirmation of inclusion criteria and absence of exclusion criteria. Then, the surgical team performed and reviewed pre-surgical laboratory and cardiopulmonary routine evaluations.

With all the proper assessments of diagnosis and surgical risk done the patient arrived to our facilities one day before the procedure for a clinical evaluation with the Amyotrophic Lateral Sclerosis Functional Rating Scale Revised (ALSFRS-R)..$^{57}$

\section{Procedure}

The procedure was performed in two facilities with access to $24 \mathrm{~h}$ intensive care unit. Under sedoanalgesia, a total of $2 \mathrm{ml} / \mathrm{kg}$ body weight of autologous BM were harvested from the posterior superior iliac crest with the regular procedure of $\mathrm{BM}$ aspiration. ${ }^{58}$ The actual extraction varied from 50 to 230 milliliters based on individual characteristics (hematocrit, $\mathrm{BM}$ available, general status, etc.). The 
BM underwent an on-site cell separation for 30 minutes in a closed system $\left(\right.$ Sepax $\left.\mathrm{II}^{\circledR}\right)$ that uses density centrifugation technique with a fixed $10 \%$ reduction rate that isolates BM-MNCs. ${ }^{59}$ Immediately after cell separation a lumbar puncture (LP), a sub occipital puncture (SOP) or both were performed after skin sterilization using not-stained Isozid- $\mathrm{H}^{\circledR}$ solution (Hexetidin, 2-Propanolol, 1-Propanolol) with a 22 Gauge Spinocan ${ }^{\circledR}$ (Fa. Braun) needle, CSF was slowly withdrawn and $2 \mathrm{ml}$ of it were collected in a plastic syringe with a plastic cap and immediately sent to laboratory analysis. The $\mathrm{ml}$ of BM-MNCs infused depended on the amount of material harvested from the iliac crest and the body weight. The BM-MNCs concentrate was infused IT (5 to $10 \mathrm{ml}$ ), IM (from 2 to $8 \mathrm{ml}$.) and/or IV (from 1 to $8 \mathrm{ml}$ ). The bone marrow plasma concentrate (BMP)obtained with the separation process was combined with $250 \mathrm{ml}$. of Lactate Ringer and infused IV (20 to $40 \mathrm{ml}$ ) and IM (from 3 to $40 \mathrm{ml}$.) immediately after IT infusion. By injecting BMP we intended to increase the concentration of secretion factors contained in the BM. After the procedure the patient remained a day for observation and then dismissed from the hospital

\section{Laboratory analysis}

Sample of BM before separation (BMB) and after it (BMA) were sent for laboratory analysis. The $\mathrm{CD} 34+$ cells were determined according to the ISHAGE guidelines ${ }^{60}$ with the Stem-kit Beckman Coulter (single platform principle with CD45FITC/CD34 PE detector). The number of CD34+ cells infused for each patient was determined by the product CD34+ cells per ml. times the number of ml. infused.

The vitality or viability of the cells was assessed with 7-Aminoactinomycin D (7-AAD) dye and conventional flow cytometer, resulting in the percentage of cells with structural integrity that reflects the percentage of live cells.

The number of leucocytes was determined by conventional technique of flow cytometry The concentration factors (CF) of $\mathrm{CD} 34+$ and leukocytes were mathematically assessed as the quotient of BMA values divided by the BMB values. The vitality reduction was determined with the same mathematic method.

\section{Follow-up}

First follow-up was the first hours after the procedure and the day after. We search for any possible acute side effects. We aimed to assess the patient at least once after the procedure. We performed ALSFRS-R and a subjective scale (with the question: Do you consider that your general clinical status is better/same vs. worse?). The follow-up was carried after 1 up to 45 months from POCST and included also side effects' survey. When the patient had more than one follow-up the last assessment for statistical analysis was considered. February 2014 was the last follow-up performed.

\section{Statistical analysis}

Variables of laboratory tests, clinical status before POCST and clinical outcome after treatment were analyzed in different sets of groups and compared to each other using non-parametric tests (Levene's $\mathrm{T}$ test for equality of variances and $\mathrm{T}$ test for equality of means, except for the variables without normal distribution in which we used Wilcoxon-Mann-Whitney test). When divided in variable groups a cut-off point of each variable was determined arbitrarily with a value around the mean of the complete sample. Linear and logarithmic regression models were performed between the variables involved. The statistical significant differences were adjusted by age.

Survival rates were determined by Kaplan-Meier curve model. ${ }^{61}$ We used the day of diagnosis as day 0 in the post-diagnostic curve and the day of intervention as day 0 in the post-treatment curve taking death as the primary endpoint in both curves. The date of diagnosis represented the date on which the diagnosis was confirmed and informed to the patient. The date of intervention represent the date on which the patient underwent POCST. We used log rank test to assess the implication of laboratory, clinical and procedure variables in the survival of the patient, also dividing the variables in two groups with the same cut-off point used in the non-parametric tests.

Confidence intervals of $95 \%$ were used, the null hypothesis was rejected when a significance of $\mathrm{p}=0,05$ was reached and when rejected the test was considered statistically significant. Graphs and analysis were performed using the IBM SPSS ${ }^{\circledR}$ statistics software version 2.0.

\section{Results}

\section{Demography}

A total of 85 patients were treated with POCST in a period of 29 months from august 2011 to December 2013. The mean age was $52,1 \pm 10,4$ y/o (29 to 76$), 67,1 \%(n=57)$ were men and $32,9 \%(n=28)$ were women. The origin of the patients was worldwide distributed with a predominance of Germans $(60 \%)$, Austrians $(7,1 \%)$, Serbians $(5,9 \%)$ and Italians $(5,9 \%)$.

\section{Initial clinical assessment}

In the initial assessment the patients had a mean ALSFRS-R of $28,9 \pm 10,8$ (5 to 46 ) and $66,6 \%$ were in the upper half of the scale. The regression models revealed a statistically significant relationship between higher ALSFRS-R and less time passed since the diagnosis to the transplantation (linear $\mathrm{p}=0,030$ and logarithmic $\mathrm{p}=0,002$ ).

\section{BM extraction}

The mean ml. of BM taken were $137,4 \pm 36,8 \mathrm{ml}$. (40 to 230 ). Patients with more than $130 \mathrm{ml}$ extracted from BM compared to those with less than $130 \mathrm{ml}$. extracted had statistically significant less CD34+ cells $/ \mathrm{ml}$ in the $\operatorname{BMB}(97,1 \pm 109$ vs. $174,9 \pm 186,9 / \mathrm{ml}[\mathrm{n}=66] ; \mathrm{p}=0,025)$ but more in the BMA $(791,6 \pm 676,3$ vs. $485,5 \pm 504,6 / \mathrm{ml}[\mathrm{n}=63]$; $\mathrm{p}=0,025)$, less leukocytes $/ \mathrm{nl}$ in BMB $(13,7 \pm 15,3$ vs. $65,5 \pm 127,3 / \mathrm{nl}$ $[\mathrm{n}=65] ; \mathrm{p}<0,001)$ and more vitality in BMB $(89,5 \pm 5,2$ vs. $85,3 \pm 7 \%$ $[\mathrm{n}=65] ; \mathrm{p}=0,008)$ but less vitality in BMA $(67,5 \pm 13,5$ vs. $77,7 \pm 10,2$ $\%[\mathrm{n}=10,2] ; \mathrm{p}=0,001)$, had higher $\mathrm{CF}$ of $\mathrm{CD} 34+$ cells $(11,7 \pm 9,3$ vs. $4,4 \pm 4,4$ times reduced $[n=65] ; p<0,001)$ and lower reduction of vitality $(0,75 \pm 0,1$ vs. $0,9 \pm 0,1$ times reduced $[n=60] ; p<0,001)$.

Regression models showed statistically significant relationship between patients that had more ml. extracted from BM and younger age (linear $\mathrm{p}=0,025$ and logarithmic $\mathrm{p}=0,027$ ) and between more ml. extracted and earlier deaths (logarithmic $\mathrm{p}=0,044$ ). A direct proportional statistically significant relationship between $\mathrm{ml}$. taken from BM and ml. of BM-MNCs concentrate infused IT (linear and logarithmic $\mathrm{p}<0,001)$ as well as with more CD34+ cells infused IT (linear $p=0,001$ and logarithmic $p=0,002$ ) was found. The patients with more ml. extracted also had statistically significant more ml. of BMP infused IV (linear $p=0,004$ and logarithmic $p=0,001$ ). The relationship was also statistically significant between more ml. of BM extract and 
less leukocytes/nl in BMB (linear 0,012 and logarithmic 0,016), more $\mathrm{CD} 34+/ \mathrm{ml}$ in BMA (linear $\mathrm{p}=0,037$ and logarithmic $\mathrm{p}=0,024$ ), less vitality in BMA (linear $\mathrm{p}=0,030$ and logarithmic $\mathrm{p}=0,011$ ), more $\mathrm{CF}$ for CD34+ cells (linear $\mathrm{p}=0,010$ and logarithmic $\mathrm{p}=0,009$ ) and more vitality reduction (linear $\mathrm{p}=0,021$ and logarithmic $\mathrm{p}=0,014$ ).

\section{BM-MNCs concentrate infused}

The mean ml. of BM-MNCs concentrate infused IT was $7,9 \pm 2,9 \mathrm{ml}$. (2 to 20 ), $4,8 \pm 1,2 \mathrm{ml}$. ( 2 to 8 ) IM and $2,3 \pm 1,3 \mathrm{ml}$ (1 to 8 ) IV. The mean ml. of BMP infused IM was $36,6 \pm 6,9 \mathrm{ml}$. (20 to 40 ) and $22,2 \pm 13 \mathrm{ml}$ (3 to 40 ) IV.

Patients with more than $5 \mathrm{ml}$. of BM-MNCs concentrate infused IT had lower ALSFRS-R in the follow-up ( $29 \pm 10$ vs. $43 \pm 1$ [n=15]; $\mathrm{p}<0,001)$ and died earlier since the diagnosis $(5,4 \pm 2,5$ vs. $9 \pm 5,9$ $[\mathrm{n}=13] ; \mathrm{p}=0,05)$, however the amount of ml. infused IT had not statistical significant relations in the regression models. The $\mathrm{ml}$. of BM-MNCs concentrate infused IM did not have any statistical significant differences between more and less than $4 \mathrm{ml}$. infused and had no statistical significance in regression models. The patients with more than 20milliliters of BMP infused IV had lower ALSFRS-R in the follow-up $(27 \pm 21,2$ vs. $41,3 \pm 5,5$ [n=5]; $\mathrm{p}=0,005)$, without statistical significance in the regression models. The IM infusion of more or less than $30 \mathrm{ml}$. BMP did not produce statistical significant differences between groups.

\section{CD34+ cells infused}

The mean number of CD34+ cells infused IT was 5,7 $\pm 5,6$ millions (1,3 to 26$), 3,6 \pm 3,6$ millions (2,9 to 15$) \mathrm{IM}$ and $1,5 \pm 1,6$ millions (65thousand to 6,6 millions) IV.

Patients with more than 5millions CD34+ cells IT had not statistical significant differences with patients infused with more than 5millions CD34+ cells IT, also did not present statistical significant relationships in the regression models between number of CD34+ cells infused IT and clinical parameters. The patients with more than 4millions of CD34+ cells infused IM had better ALSFR-S in the follow-up ( $36 \pm 1$ vs. $28,4 \pm 9,9[\mathrm{n}=10] ; \mathrm{p}=0,002)$ however they had not statistical significant relationships in the regression models. The difference between more and less than 1million cells infused IV had not any statistical significant differences neither statistical significant relationships in the regression models.

\section{BM samples}

The BMB had a mean number of CD34+ cells/ml of $115,3 \pm 135,8$ $\mathrm{ml}(8$ to 892$)$ with a mean vitality of $86,7 \pm 8 \%(59,9$ to 99,9$)$ and a mean number of leukocytes/nl of $29,4 \pm 73,4 / \mathrm{nl}(0,8$ to 512,6$)$. The BMA had a mean number of CD34+ cells $/ \mathrm{ml}$ of $695,1 \pm 624,9 / \mathrm{ml}(43,5$ to 2920$)$ with a mean vitality of $71 \pm 13,9 \%(25,8$ to 93,8$)$ and a mean number of leukocytes/nl of $140,8 \pm 149,4 / \mathrm{nl}(12,1$ to 815,2$)$. The mean CF was $9,3 \pm 8,2$ times $(0,5$ to 32,5$)$ for CD $34+$ cells, $12,5 \pm 14,6$ times $(0,1$ to 95,6$)$ for leukocytes and the vitality was 0,8 times reduced $(0,36$ to 1,32$)$. The differences between means of BMB and BMA were statistically significant for the three measurements $(p<0,001)$.

The group with more than $100 \mathrm{CD} 34+$ cells $/ \mathrm{ml}$ in BMB compared to the ones under $100 \mathrm{CD} 34+$ cells $/ \mathrm{ml}$ in the same sample had statistically significant more vitality $(87,2 \pm 5,1$ vs. $86,4 \pm 9,5 \%[\mathrm{n}=78]$; $\mathrm{p}=0,019)$, more leukocytes/nl $(56 \pm 110,4$ vs. $11,4 \pm 12,2 / \mathrm{nl}[\mathrm{n}=77]$; $\mathrm{p}=0,001)$, lower $\mathrm{CF}$ of $\mathrm{CD} 34+$ cells $(6,1 \pm 6,9$ vs. $11,5 \pm 8,4$ times $[\mathrm{n}=73] ; \mathrm{p}=0,004)$, lower CF of leukocytes $(7,4 \pm 6,2$ vs. $15,7 \pm 17,3$ times $[\mathrm{n}=64] ; \mathrm{p}=0,017)$ and more time passed between diagnosis and POCST $(24,9 \pm 27$ vs. $21,1 \pm 16,3$ months $[\mathrm{n}=80] ; \mathrm{p}=0,039)$. The regression models were statistically significant between high number of CD34+cells $/ \mathrm{ml}$ in BMB and low CF of CD34+cells (linear $\mathrm{p}=0,002$, logarithmic $\mathrm{p}<0,001)$ and between high number of CD34+cells $/ \mathrm{ml}$ $\mathrm{BMB}$ and high levels of leukocytes/nl (linear $\mathrm{p}<0,001$, logarithmic $\mathrm{p}=0,001)$.

The group with more than $500 \mathrm{CD} 34+$ cells $/ \mathrm{ml}$ in BMA compare to the patients with less than $500 \mathrm{CD} 34+$ cells $/ \mathrm{ml}$ in the same sample had statistically significant higher vitality $(71,2 \pm 10,7$ vs. $70,8 \pm 16,5$ $\%[\mathrm{n}=73] ; \mathrm{p}=0,036)$ and less time passed since diagnosis to POCST $(21,8 \pm$ vs. $23,8 \pm$ months $[\mathrm{n}=73] ; \mathrm{p}=0,047)$, without statistical significance in regression models.

\section{Vitality}

Patients with more than $80 \%$ of vitality in BMB compared to those with less than $80 \%$ in the same sample had less reduction of vitality $(0,7 \pm 0,1$ vs. $0,8 \pm 0,2[\mathrm{n}=70] ; \mathrm{p}=0,001)$. The regression models were statistically significant between high percentage of vitality in $\mathrm{BMB}$ and high ALSFRS-R in the follow-up (linear and logarithmic $\mathrm{p}=0,009)$.

The group with more than $80 \%$ of vitality in BMA compared to those with less than $80 \%$ in the same sample were younger $(51,4 \pm 7,6$ vs. $52,7 \pm 10,8 \mathrm{y} / \mathrm{o}[\mathrm{n}=73] ; \mathrm{p}=0,=01)$, had more time passed between diagnosis and POCST $(26,7 \pm 31,4$ vs. $21,92 \pm 17,3$ months $[\mathrm{n}=72]$; $\mathrm{p}=0,049)$, lower ALSFRS-R before POCST $(28,5 \pm 13,8$ vs. $30,2 \pm 9,5$ $[n=36] ; p=0,035)$ but higher ALSFRS-R after POCST (31,6 $\pm 13,2$ vs. $28,8 \pm 7,5[\mathrm{n}=18] ; \mathrm{p}=0,041)$ and died later after POCST $(6,8 \pm 5,5$ vs. $5,6 \pm 2,5$ months $[\mathrm{n}=16] ; \mathrm{p}=0,049)$. The regression models were not statistically significant.

\section{Leukocytes/nl}

Patients with more than 12 leukocytes/nl in BMB compared to the group with less than 12 leukocytes/nl in the same sample had lower vitality $(86 \pm 7,6$ vs. $89,2 \pm 5,7 \%$ [n=76]; $\mathrm{p}=0,042)$, lower $\mathrm{CF}$ of CD34+ cells $(7 \pm 7$ vs. $12.6 \pm 8,8$ times $[\mathrm{n}=70] ; \mathrm{p}=0,004)$, lower $\mathrm{CF}$ of leukocytes $(7,4 \pm 7,1$ vs. $17,6 \pm 18,1$ times $[\mathrm{n}=64] ; \mathrm{p}=0,016)$ and more reduction of vitality $(0,8 \pm 0,1$ vs. $0,7 \pm 0,1$ times reduced $[n=69] ; p=0,037)$. The regression models were significant between high leukocytes/nl and low vitality in $\mathrm{BMB}$ (Logarithmic $\mathrm{p}=0,043$ ), between high leukocytes/ $\mathrm{nl}$ in $\mathrm{BMB}$ and low $\mathrm{CF}$ of CD34+cells (logarithmic $\mathrm{p}=0,001$ ), between high leukocytes/nl in BMB and low CF of leukocytes (logarithmic $\mathrm{p}<0,001$ ), between high leukocytes/nl in BMB and high reduction of vitality (logarithmic $\mathrm{p}=0,011)$.

The group with more than 100 leukocytes/nl in BMA compared to the ones with less than 100 leukocytes/nl in the same sample had higher CD34+ cells $/ \mathrm{ml}(1064,5 \pm 736,3$ vs. $359,7 \pm 252,5 / \mathrm{ml}[\mathrm{n}=67]$; $\mathrm{p}<0,001)$, higher vitality $(74 \pm 10,6$ vs. $67,8 \pm 16,6 \%[\mathrm{n}=67] ; \mathrm{p}=0,02)$ and higher ALSFRS-R before N-POCST $(31,1 \pm 13,5$ vs. $28,5 \pm 8,6 \%$ [34]; $p=0,012)$. The regression models were statistically significant between high leukocytes/nl and high CD34+cells/ml in BMA (linear and logarithmic $\mathrm{p}<0,001$ ), between more leukocytes/nL and high vitality in BMASS (logarithmic $\mathrm{p}=0,037$ ).

Patients older than $50 \mathrm{y} / \mathrm{o}$ had more leukocytes $/ \mathrm{nl}$ in BMB than Youngers than 50 y/o $(39,3 \pm 93,6$ vs. $14,7 \pm 11,4 / n 1$ [n=77]; $p=0,021)$ without statistical significance in the regression models. The group 
in the lower half compared to the upper half of ALSFRS-R before POCST had more leukocytes/nL in BMB $(55,6 \pm 112,7$ vs. $12,1 \pm 12,7$ / $\mathrm{nL}[\mathrm{n}=37] ; \mathrm{p}=0,004)$.

\section{Follow-up}

The mean follow-up was $30,6 \pm 26,8$ (3-149) months after diagnosis and $7,1 \pm 6(1-45)$ months after POCST. No patient presented with a major side effect in the short or long term, $40 \%$ of the patients had headache secondary to the lumbar puncture that resolve with regular treatment. We collected medical information retrospectively in order to have an assessment of survival since the moment of the diagnosis, however we had personal follow-up with the patients just from the moment of the treatment.

\section{ALSFRS-R}

$22,3 \%(19)$ of the patients completed at least one follow-up with ALSFRS-R after POCST by an experienced physician, from the nonfollowed $22,7 \%(15)$ were due to death before assessment and the other $77,2 \%(51)$ were unable to return for ALSFRS-R assessment for other non-disease related reasons.

The ALSFRS-R after the mean follow-up period was $29,5 \pm 10,1$ from the moment of intervention(12-45). When before and after the procedure just the individuals that complete a proper follow-up, the mean ALSFRS-R went from 33,3 $\pm 10,5$ to $29,5 \pm 10,1$ (SD 5,2 with $95 \% \mathrm{CI}$ from 1,1 to 6,2 ) (Figure 1). No single patient improved the score, however $52,6 \%$ of them maintained the same score and $47,3 \%$ had a lower score during the first period of time (Figure 2). There were no statistically significant differences between clinical or laboratory variables between the group that maintained the ALSFRS-R and the group that had deterioration of the ALSFRS-R.

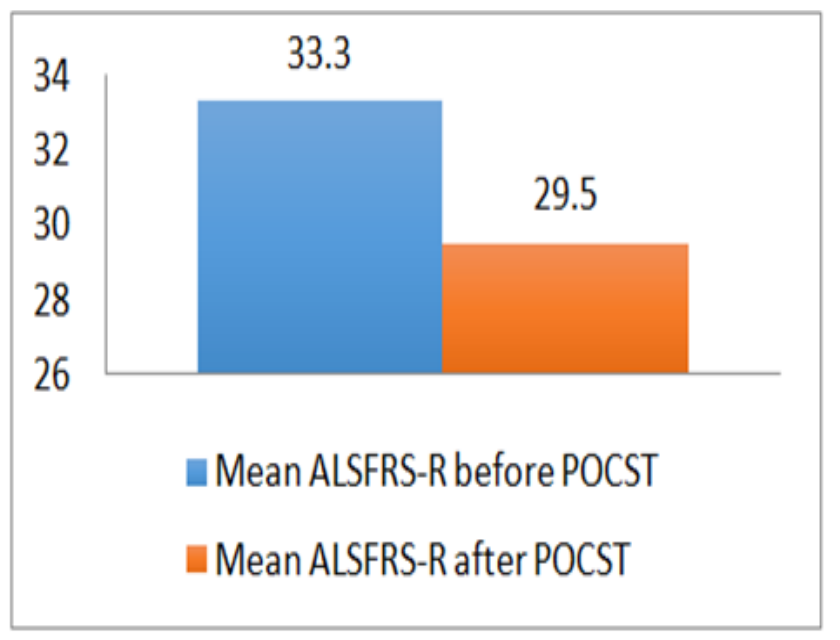

Figure I From the moment of SC treatment.

Patients were divided into groups of upper and lower half of the ALSFRS-R after N-POCST. The patients in the lower half of ALSFRS-R after the POCST compared to the upper half had statistically significant higher levels of CD34+ cells/ml $(204,6 \pm 307,9$ vs. $89,6 \pm 64,5 / \mathrm{ml}[\mathrm{n}=19]$; $\mathrm{p}=0,038)$ with lower vitality $(84,6 \pm 5$ vs. $89,8 \pm 2 \%[\mathrm{n}=19] ; \mathrm{p}=0,040)$ in BMB and higher levels of leukocytes in $\operatorname{BMB}(74,2 / \mathrm{nl} \pm 147,2$ vs. $14,4 / \mathrm{n} 1 \pm 8,7[\mathrm{n}=19] ; \mathrm{p}=010)$ and in BMA $(218,3 \pm 302,4$ vs. $143,2 \pm 106,9 / \mathrm{nl}[\mathrm{n}=17] ;[\mathrm{p}=043])$. The logarithmic regression models were statistical significant for high percentage of vitality in BMB and high levels of ALSFRS-R after N-POCST (linear $\mathrm{p}=0,009$ and logarithmic 0,006 ) and for low levels of leukocytes/nl in BMBSS and high ALSFRS-R after POCST (logarithmic $\mathrm{p}=0,014)$.

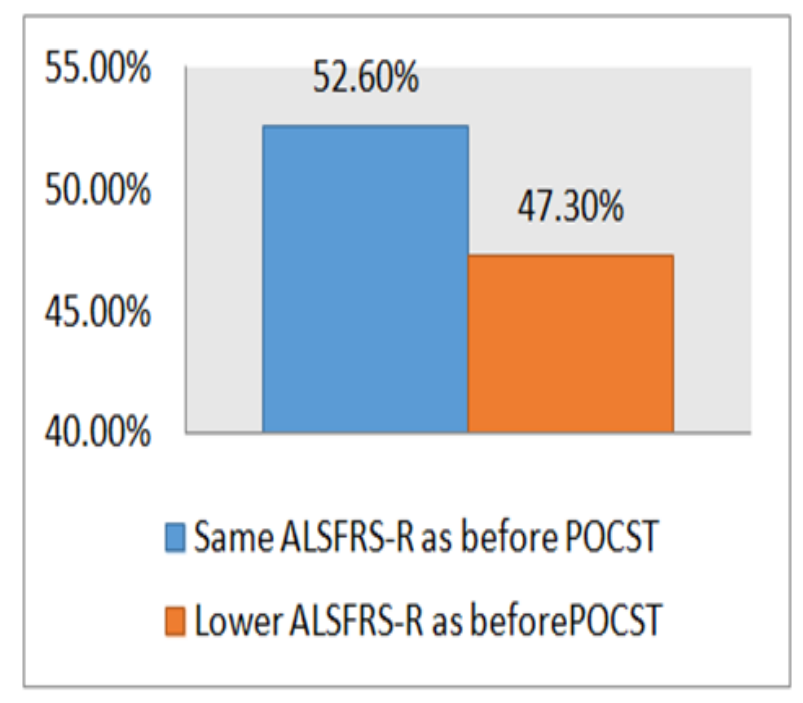

Figure 2 ALSFR-R mean before and after SC.

\section{Subjective follow-up}

The subjective follow-up was possible in $60,9 \%(50)$ of the patients while $22,7 \%(15)$ were dead before the assessment and the rest were unable to reach for non-disease reasons. From the patients assessed $26 \%(14)$ reported to feel the same or better and $74 \%(40)$ reported to feel worse. The group of patients that reports to be same or better hat statistically significant more milliliters of BMP infused IM (40 vs. $35,4 \pm 7,9 \mathrm{ml}$. [n=31]; $\mathrm{p}=0,001)$ and less reduction of vitality $(0,7 \pm 0.2$ vs. $0,8 \pm 0,12$ times $[\mathrm{n}=47] ; \mathrm{p}=0,006)$.

\section{Survival}

A $22,4 \%(19)$ of patients died in a mean period of $22,84 \pm 14$ (4 to 64) months after diagnosis and 7,21 $\pm 4(1-17)$ after the POCST. Earlier deaths were found statistical significant higher in men $(6,2 \pm 3,4$ vs. 9,3 $\pm 6,2$ months $[n=19] ; p=0,047)$, patients with more than 100 CD34+ cells/ml in BMB $(6,1 \pm 3,1$ vs. $8,4 \pm 5,7$ months $[\mathrm{n}=19]$; $\mathrm{p}=0,021)$, without sub occipital infusion $(5,4 \pm 2,9$ vs. $13,7 \pm 3,7$ months $[\mathrm{n}=19] ; \mathrm{p}<0,001)$ and without IM infusion $(20,6 \pm 9,3$ vs. $29 \pm 25,3$ months [ $\mathrm{n}=19]$; $\mathrm{p}<0,001$ ).

The patients that survive had more time passed after diagnosis $(33,5 \pm 29,8$ months vs. $22,7 \pm 14,7$ months $[\mathrm{n}=69]$; $\mathrm{p}=0,05)$, had more ml. of BM-MNCs concentrate infused IV $(2,3 \pm 1,4$ vs. $2 \pm 0,5 \mathrm{ml}$. $[\mathrm{N}=56] ; \mathrm{p}=0,025)$ and more number of $\mathrm{CD} 34+$ cells infused IV $(1,7$ vs. 1,04millions [n=52]; $\mathrm{p}=0,018)$.

The Kaplan-Meir survival curve had a mean survival of 99,3 months (SD 10,5; CI95\% 78,6 - 119,9) from the time of the diagnosis without a median survival after 149 months of follow-up (Table 1) (Figure 3). The survival mean after POCST was 23,1 months (SD 3,9; CI95\% 15,3-30,9) and the median was 17 months (SD 2,8; CI95\% 11,4 - 22,5) (Table 1) (Figure 4). The survival rates after 6 months of diagnosis were $96 \%$, after 12 months was $91 \%$, after 24 months was $84 \%$, after 60 months was $65 \%$ and after 120 months was $57 \%$ (Table 1) (Figure 4). The survival rates after treatment was $87,6 \%$ at 6 months, $52,1 \%$ at 12 months and 37,2\% at 24, 36 and 45 months (Table 1) (Figure 4). 
Table I (Part I) Survival in the present study vs. Population based studies. NA= Not available

\begin{tabular}{|c|c|c|c|c|c|c|}
\hline Study & $\begin{array}{l}\text { Follow-up } \\
\text { since }\end{array}$ & $\begin{array}{l}\text { Mean survival } \\
\text { (Months) }\end{array}$ & $\begin{array}{l}\text { Median survival } \\
\text { (Month) }\end{array}$ & $\begin{array}{l}\% \text { Survival at } \\
\text { I } 2 \text { months }\end{array}$ & $\begin{array}{l}\% \text { Survival at } 5 \\
\text { years }\end{array}$ & $\begin{array}{l}\% \text { Survival at } 10 \\
\text { years }\end{array}$ \\
\hline Present Study & Diagnosis & 99,3 & $>149$ & 98 & 65 & 57 \\
\hline Lee et al. ${ }^{22}$ & Diagnosis & NA & 66,6 & 84 & 52 & 37 \\
\hline Sorenson et al. ${ }^{80}$ & Diagnosis & 23 & NA & NA & 8 & NA \\
\hline \multirow{3}{*}{ Pupillo et al. ${ }^{79}$} & Onset & NA & 36 & 92,1 & 28,6 & 13,3 \\
\hline & & & & & & \\
\hline & Diagnosis & NA & 26 & 76,2 & 23,4 & 11,8 \\
\hline Granieri et al. ${ }^{16}$ & Onset & NA & 48 & 92 & 39,8 & NA \\
\hline Yoshida et al. ${ }^{15}$ & Onset & NA & 23,8 & 96 & 14 & 0 \\
\hline Salemi et al. ${ }^{23}$ & Onset & NA & 36 & 88 & 31,4 & 24,1 \\
\hline $\begin{array}{l}\text { Irish ALS } \\
\text { regristry }\end{array}$ & Diagnosis & NA & 22 & NA & NA & NA \\
\hline
\end{tabular}

Table 2 (Part 2) Survival in the present study vs. other treatments. NA= Not available

\begin{tabular}{|c|c|c|c|c|c|c|c|}
\hline Study & $\begin{array}{l}\text { Follow-up } \\
\text { since }\end{array}$ & $\begin{array}{l}\text { Mean } \\
\text { survival } \\
\text { (Months) }\end{array}$ & $\begin{array}{l}\text { Median survival } \\
\text { (Month) }\end{array}$ & $\begin{array}{l}\% \text { Survival at I } 2 \\
\text { months }\end{array}$ & $\begin{array}{l}\% \text { Survival at } \\
24 \text { months }\end{array}$ & $\begin{array}{l}\text { \% Survival } \\
\text { at } 36 \\
\text { months }\end{array}$ & $\begin{array}{l}\% \text { Survival at } \\
45 \text { months }\end{array}$ \\
\hline Present Study & $N=-P O C S T$ & 23,1 & 17 & 52,1 & 37,2 & 37,2 & 37,2 \\
\hline $\begin{array}{l}\text { ALS/Rilouzole } \\
\text { group }\end{array}$ & Randomization & NA & 17,7 & 71 & 49 & NA & NA \\
\hline
\end{tabular}

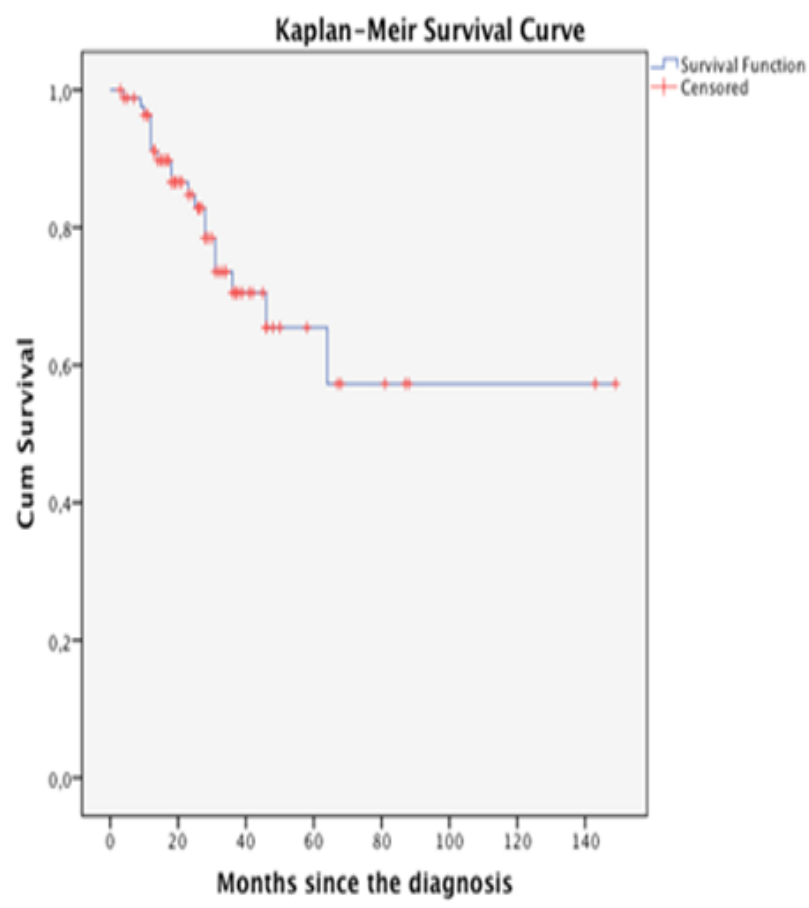

Figure 3 Rate of ALSFRS-R maintained and lowered.

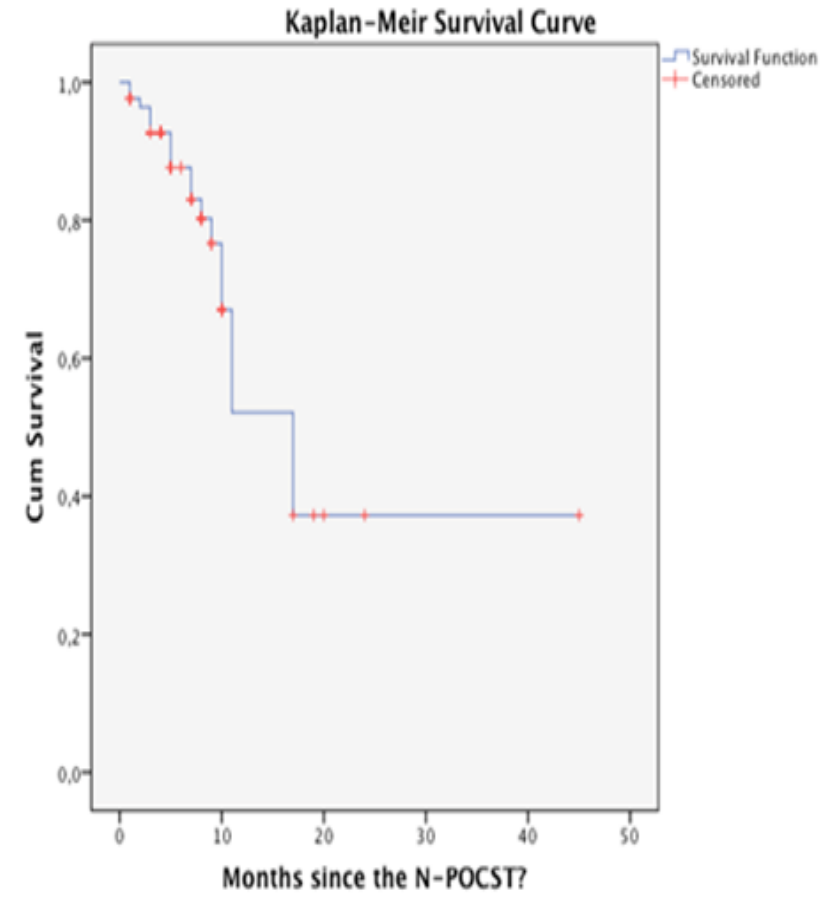

Figure 4 From the moment of diagnosis. 


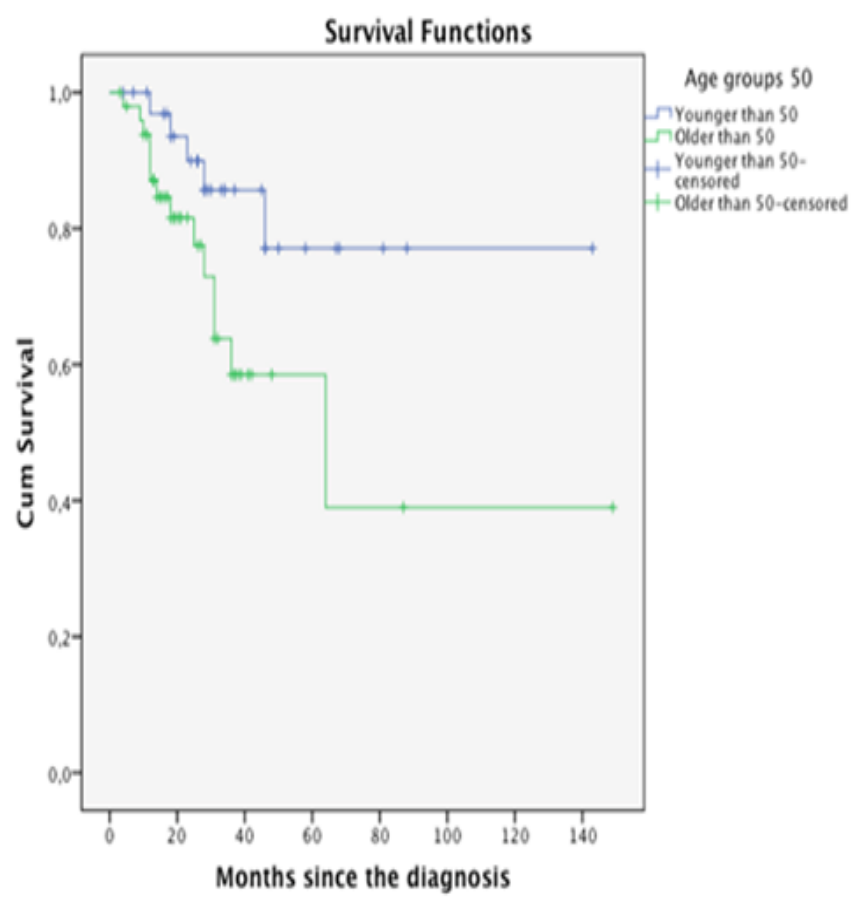

Figure 5 Log rank age groups.

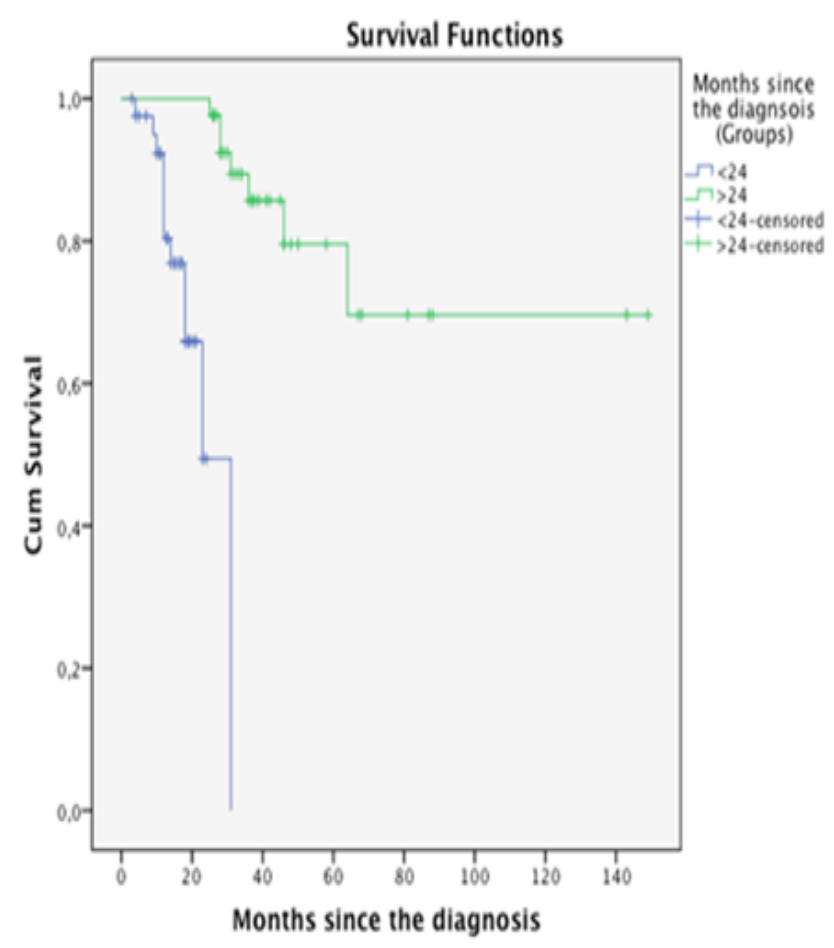

Figure 6 Log rank diagnosis time groups.

\section{Discussion}

\section{Rationale}

Previous publications described a neuroprotective and neuro regenerative effect of BM-MNCs in $\mathrm{CNS}^{28-30}$ probably due to growth factors that regulate the immune system. ${ }^{31-33}$ Besides, these BM-
MNCs that include mesenchymal (MSCs) and hematopoietic stem cells (HSCs) have been specifically described in ALS models to regenerate motoneurons, ${ }^{41-44}$ replace astrocytes contributing to slow motoneuron loss, ${ }^{45}$ regenerate microglia ${ }^{46,47}$ and secrete growth factors promoting maintenance of healthy motoneurons. ${ }^{48,49}$ Furthermore, other models point-out that BM-MNCs infusion via $\mathrm{IT}^{50}$ or $\mathrm{IM}^{51}$ have major beneficial effects in ALS. Therefore, and together with safety profiles described by other authors infusing SCs IT in ALS and other diseases $^{52,53,62-72}$ the use of BM-MNCs via IT, IM and IV in humans with ALS is rational.

\section{Population}

Our sample reproduces same characteristics of populationbased studies of ALS ${ }^{2,12,73,74}$ with a mean age of 52,1 y/o and male predominance. Moreover, the patients had different countries of origin making our results more universal for different populations.

The mean ALSFRS-R before POCST was above half scale. As expected, patients with a more rapid decline in health are more likely to seek the assistance of SCT. Indeed, all patients had a decline in their clinical status, in spite of the fact that all of them where under Riluzole or other combination of treatments. Hence, we can conclude that Riluzole was not the main factor of stabilization. We included all patients regardless the ALSFRS-R in order to prevent selection bias, however more than $50 \%$ of patients turned out to have ALSFRS-R in the upper half. This fact may have influenced the positive outcome after POCST. However, a correlation between ALSFRS-R before POCST and outcome was not found. Still, we found correlations between ALSFRS-R before POCST and BM contents that maybe consider in the futrue as a predictor of treatment success, however not as an isolate factor.

\section{Bone marrow aspiration}

The aspiration of $\mathrm{BM}$ was variable because different content available in patients' iliac crest; as expected high amounts of BM available were related to youth. We measured CD34+ being international accepted as a marker of obtaining SCs from BM and not just sinusoidal blood even it is an specific marker for HSCs reports also correlate the number of HSC to MSC and an indirect amount of all mononuclear cells.

Patients with more volume of BM available for aspiration had less CD34+ cells $/ \mu 1$ and more vitality in BMB notwithstanding had more CD34+ cells $/ \mu$ land less vitality in BMA. For CD34+ cells $/ \mathrm{ml}$ means that after separation they concentrate with efficacious dismissing of BM's unnecessary portion secondly the vitality reduction is probably due to cell destruction during separation.

We saw that a minimum of $100 \mathrm{CD} 34+$ cells $/ \mathrm{ml}$ in $\mathrm{BMB}$ and a minimum of $500 \mathrm{CD} 34+$ cells $/ \mathrm{ml}$ in BMA accounts for higher vitality than samples with $\mathrm{CD} 34+$ cells $/ \mathrm{ml}$ below these values. Hence high vitality seems to depend inter alia on high number of CD34+ cells/ $\mathrm{ml}$ and the $\mathrm{CD} 34+$ cells $/ \mathrm{ml}$ depends on more BM's volume available. Also, more volume aspirated and processed account for higher $\mathrm{CF}$ of $\mathrm{CD} 34+$ cells and lower vitality reduction. Consequently, the importance of having enough BM available results in a more effective concentration.

We can conclude that even the separation process always represent vitality reduction it provides the sufficient characteristics of SCs for infusion with the maximum number of $\mathrm{CD} 34+$ and highest vitality possible per ml. High volume of BM available for aspiration correlates 
with early deaths. Then, patients with high levels of CD34+ cells $/ \mathrm{ml}$ in BMB and more than $80 \%$ of vitality in BMA had more time passed since diagnosis to POCST, highlighting that high CD34+ cells $/ \mathrm{ml}$ and high vitality represent probably more advanced disease suggesting that BM samples alone are probably not the best outcome predictor.

These findings are extremely critical also to explain possible pathophysiological aspects of ALS. The patients that had more time passed since diagnosis hence probably more advanced disease and worse clinical status had apparently better BM conformation while they have more $\mathrm{CD} 34+$ cells $/ \mathrm{ml}$ and more vitality, however after the separation the ones that maintain more than $\mathrm{CD} 34+$ cells $/ \mathrm{ml}$ were the ones with less time since diagnosis meaning less evolution of diseases. This can result because patients with more advanced disease had poor quality of SCs and even they have more cells a simple density centrifugation reduce they viability and number. Therefore, a cornerstone for the pathophysiology could be suggested. Several scientific groups described that normal functioning bone marrowderived SCs mobilize and migrate into injured tissue where they participate in the process of repair, in parallel to these, a considerable number of recent studies have associated the development of several degenerative disease with a reduced number of circulating SCs in peripheral blood, this data together provide a possible understanding in which degenerative diseases do not develop just due to intrinsic cellular loss or external factors but also following an imbalance between cellular loss and tissue renewal. ${ }^{29,75}$ Supporting these descriptions, in our sample the patients with advanced disease previous to treatment are probably producing a strong signal to BM that makes a highly active SCs production and high CD34+ cells $/ \mathrm{ml}$, however the lack of migrating capacity or functional deficiency, not measured but assumed by the low resistance to centrifuge, causes an imbalance in tissue renewal. These assumptions should be further confirm by sampling SCs levels in peripheral blood and BM of the same patient. ${ }^{76}$ Moreover, with analysis of BM and peripheral blood content we could create prognosis scales.

These findings also support the rationale of PCOST, as we infused SCs directly in the affected organs (CNS and muscle) in intent to overcome the lack of migration capacity. Even the probable functional deficiency is not changed by POCST the treatment could reduce or stop the imbalance of tissue renewal in affected moto neurons and surrounding implicates by a kind of system "restart".

\section{Infusion}

The correlation between $\mathrm{ml}$. of $\mathrm{BM}$ extracted with $\mathrm{ml}$. of BM-MNCs infused IT was directly proportional supporting the homogeneity of the technic in all patients.

\section{BM-MNCs concentrate infused}

The patients with more than $5 \mathrm{ml}$. of BM-MNCs infused IT and more than 20ml. BM-MNCs infused IM had poorer ALSFRS-R after N-POCST, the first ones also died earlier. With these findings we can assume that the amount of ml. concentrate infused is not the most important aspect alone as patients with high amounts of concentrate infused do not necessary have more CD34+ cells per ml infused with high vitality and normal function capacity.

\section{Number of CD34+ cells infused}

Patients with more than 4 million CD34+ cells infused IM had a clear statistical significant relation with high ALSFRS-R after the POCST, the number of CD34+ cells infused IT or IV did not had statistical significant correlations with outcome or mortality. We can assume that probably in patients with ALS a minimal dose of 4 millions cells infused IM is required to obtain a positive outcome supporting the importance of IM infusion described before in animal models by Suzuki et al. ${ }^{51}$ This is the first approach of a minimum dose to achieve positive outcome in humans with ALS.

\section{CD34+ cells/ml in BM samples}

High levels of CD34+ cells $/ \mathrm{ml}$ were directly related to high number of leukocytes/nl in BMB. As we described before these high levels of $\mathrm{CD} 34+$ cells $/ \mathrm{ml}$ are also related to worse clinical status, thus the leukocytes are probably interfering in the migrating capacity of the SCs reducing the possibility of the own body to overcome the renewal imbalance.

High vitality before and after separation is also related to high $\mathrm{CD} 34+$ cells $/ \mathrm{ml}$. An expected phenomenon due to the fact that more $\mathrm{CD} 34+$ cells $/ \mathrm{ml}$ available before the separation process even if the $\mathrm{BM}$ is defective will account for more viable cells.

As we addressed before the more $\mathrm{ml}$. extracted of $\mathrm{BM}$ the higher $\mathrm{CF}$ for $\mathrm{CD} 34+$ cells they had, however the higher number of CD34+ cells $/ \mathrm{ml}$ in the BMB the lower $\mathrm{CF}$ of $\mathrm{CD} 34+$ cells obtained. The same phenomenon occurs with leukocytes. These describe an expected CF capacity of a more diluted solution.

\section{Vitality of CD34+ cells in samples}

The vitality is also called viability meaning which percentage of cells is structural complete and represents alive cells. The patients with more than $80 \%$ vitality in BMB had less reduction in vitality with separation, thus a high initial vitality is important to minimize the vitality reduction effect of the separation process. The preservation of vitality after separation was also better in young patients. We found that vitality plays an important role in patients' improvement while high vitality in BMA correlates with high ALSFRS-R after the POCST making vitality a cornerstone of outcome predictor to POCST. Furthermore, when we look at patients with more than $80 \%$ in BMA before POCST they had lower ALSFRS-R meaning that is reversed after POCST. A conclusion arise that patients with worse clinical status but with high levels of vitality are probably the most beneficiated from the treatment.

To complement the outcome predictor capacities of vitality we found that patients with more than $80 \%$ of vitality in BMA had more survival time after the POCST. This clinical correlation between high vitality and better outcome after the POCST point out the importance of these measure to approach in predict response to treatment, by means we need not just a high amount of CD34+ cells but also alive cells that resist to separation. We can determine that a minimum of $80 \%$ of vitality in the samples in BMA maybe necessary to present a clinical improvement.

\section{Leukocytes/nl in samples}

The patients with more leukocytes/nl in BMB had lower levels of vitality in the same sample, lower CF of CD34+ cells, lower CF of leukocytes itself and more reduction in vitality. This could be understood as chronic inflammatory response to external or internal agents that produces constant high levels of leukocytes interfering in the correct production and maintenance of $\mathrm{CD} 34+$ cells, vitality and migration capacity in patients' BM in vivo interfering in the renewal balance, as addressed in previous paragraphs. 
Probably, these high amounts of leukocytes also interfere in a correct separation process ex vivo promoting high reduction of vitality and low concentration of CD34+ cells. However after separation the vitality relation to leukocytes is inverted, meaning that even high leukocytes accounts interfere in separation process the process itself could maximize the quality of SCs to be infused regardless the in vivo obstacles supporting the method use without further cell manipulation.

The high levels of leukocytes/nl were found in patients with lower ALSFRS-R before the treatment. We also found that BMA high levels of leukocytes $/ \mathrm{nl}$ are related to high $\mathrm{CD} 34+$ cells $/ \mathrm{ml}$ and older patients. Together we the above descriptions of $\mathrm{CD} 34+$ cells $/ \mathrm{ml}$ reinforce a profile of patients with worst clinical status regardless the treatment.

In BMB high levels of leukocytes/nl are related to low ALSFRS-R after POCST. These results lead us to think that high levels of leukocytes in BM could complement an outcome predictor after POCST together with vitality.

The older patients had more leukocytes/nl in BMB; if we combine the fact that old patients had less BM available with more content of leukocytes we could explain why younger patients had more survival rates. With our results we can also determine $50 \mathrm{y} / \mathrm{o}$ as a cutoff point of better response to POCST.

\section{Clinical outcome}

\section{Safety}

The first important issue to describe is that none of our patients had any major side effect derived from the procedure; just $40 \%$ of them had mild headaches secondary to the lumbar puncture that was resolved after 48 hours maximum with regular analgesic medications. These confirms and reassure the previous findings by other groups about the safety of the IT infusion of SCs. ${ }^{52,53,68-70,72,77}$

\section{ALSFRS-R}

We performed follow-up to patients in short and long term, from 1 to 45 months after POCST. We used ALSFRS-R because is considered a highly accurate measure of ALS progression. ${ }^{57}$ Comparing the mean ALSFRS-R, only from the patients that complete the follow-up, we found a decrease in progression rate with only 3,8 reduction points in a 7,1 moths mean follow-up (Figure 1). Moreover, when we compared patient by patient individually, $52,6 \%$ of them maintained the same score, revealing not just a decrease in progression rates but also a stabilization of the disease in the majority of our patients (Figure 2).

Our results support the safety of the method and add unique information about the effectiveness of autologous stem cells to treat ALS supporting previous reports that described safety, feasibility and in some cases stop of the functional declination. . $2,53,68-70,72,77^{-17}$

\section{Subjective assessment}

ALS is a complex disease without single ideal scale of measurement that describes an improvement or stabilization. Therefore, we decided also to evaluate subjective parameters in the patients even knowing that these could be influenced by placebo effect, especially without a blinded control group. We found $26 \%$ of our patients with subjective stabilization that actually correlate with higher vitality in BMA and lower vitality reduction. The fact that the vitality in BMB is inverted can also reinforced previous comments that described patients with better clinical status have cells that resist normally to separation and even they have less vitality before separation the process potentiate
SCs capacity. Moreover, patients with better subjective outcome were the ones with more $\mathrm{ml}$. of BMP infused IM remarking again the importance of IM infusion not only in number of CD34+ cells but also amount of BMP.

\section{Survival}

It is accepted that the primary measurement that measures the effect of ALS treatments is survival rates. ${ }^{8}$ Survival ranges are from months to decades, however it is usually less than 2 to 3 years since the appearance of symptoms. ${ }^{9}$ Outcome after different treatments or the combination of them as multidisciplinary care varies from one study to another mainly because different starting points, thus is difficult to compare populations from one study to another. ${ }^{7}$ However, due to the fact that we did not have control groups we compared our results to survival rates of population-based studies (Table 1, Part 1). We also compared our sample with Riluzole as single treatment (Table 1, Part 2).

A total of $22 \%$ of the patients died. In general we found that men and patients with more $\mathrm{CD} 34+$ cells $/ \mathrm{ml}$ died earlier as well as patients with more $\mathrm{CD} 34+$ cells $/ \mathrm{ml}$, supporting once again that the high number of $\mathrm{CD} 34+$ cells $/ \mathrm{ml}$ accounts for patients with worse clinical status and is probably due to the migration incapacity of SCs and the consequent ineffective tissue renewal. Important to highlight is that $\mathrm{CD} 34+$ cells $/ \mathrm{ml}$ in BM alone cannot be predictive of survival.

Patients that died earlier did not have SOP or IM infusion, highlighting the importance of SCs IM infusion not just for the clinical status but for survival. Even SOP infusion did not conferee any differences in the ALSFRS-R and clinical outcome it actually inferred in the velocity of progression to death, we should further determine cost-benefit of SOP while even SOP impacts positive in survival may conferee more risk than LP in individual cases.

Mortality was also influenced by low $\mathrm{ml}$. of BM-MNCs and low number of CD34+ infused IV, however we could not determine minimum $\mathrm{ml}$. as in the IM infusion and the previously mention aluminum levels.

The groups with better survival rates were the patients younger than $50 \mathrm{y} / \mathrm{o}$ reinforcing that this age group benefit more from POCST. Also, patients with more than 24 months passed since diagnosis had higher survival rates, this could be explained because these patients have more $\mathrm{CD} 34+$ cells $/ \mathrm{ml}$ available that accounts for more vitality to be infused than patients with short evolution of disease probably because SCs accumulate in BM after long time of receiving strong signal of damaged moto neurons for tissue renewal, then POCST overcomes the migration incapacity by infusing them directly.

\section{Compared to population-based studies}

The contrasting results in based-population reports maybe due to sample bias, disease varieties, diagnostic and follow-up criteria, but mainly due to the plethora of symptoms of ALS. ${ }^{78}$ However, we compared our sample mainly with a recent survey published by Pupillo et al., ${ }^{79}$ in which they pointed out and tried to overcome these errors and bias by a comprehensive method. In this study a cumulative time-dependent survival at 1,5 and 10 years of $76.2 \%$, $23.4 \%$ and $11.8 \%$ respectively from the moment of diagnosis with a median survival of 26 months is described. ${ }^{79}$ Compared to their results our patients had extremely higher median survival of more than 149 months (Table 1). However, the median is not yet exact because we did not reached $50 \%$ of mortality (Table 1 and Figure 3). We could 
not compare our mean survival of 99,3 months with this study because they had not reported any mean (Table 1). Comparing to these results our patients had an increased survival of $21.8 \%$ in the first year, $41,6 \%$ in 5years and $45.2 \%$ in 10years after the diagnosis. These data support the hypothesis that POCST is an effective treatment that probably remains effective and improved patients' long-term clinical status.

The majority of population-based studies take the onset of symptoms as point 0 for survival. However, this makes it more difficult to standardize the sample because the onset of symptoms is confused for the majority of patients. As a matter of fact almost $50 \%$ of the patients had surgery for various orthopedic diagnoses which later where acknowledged as ALS. We decided to take point 0 as time of diagnosis even this could mislead the comparison to other studies, setting our patients appearing to have worse status in less time. Nevertheless, there is no study with better outcome compared to our data at 1,5 or 10years of follow-up (Table 1)..$^{14,15,22,73,80}$

In previous studies with small samples and short follow-up the results trend to pullout an unexpected decrease in survival. In our sample, even if it is relatively small and heterogeneous, the survival is outstanding (Table 1).

All the patients treated in this study received a single infusion of stem cells. However, we have experienced in patients treated recently that several infusions in regular basis have better results and maintain the positive effects for more time. This has been also supported by other authors. In the future, the treatment with SCs maybe not considered as a single infusion but as a long-term treatment of maintenance.

\section{Compared to other treatments}

There is no cure for ALS and the current efforts are mostly focused to maintain and to prolong it by a multidisciplinary approach. ${ }^{2}$ The Irish ALS registry describes a median survival of 22 months since diagnosis in patients treated in a multidisciplinary clinic and 14 months in patients attending a general neurology clinic. ${ }^{7}$ Our patients had an increased survival by 27 months probably related to POCST (Table 1).

\section{The Riluzole case}

In the first description by Benisimon G., the rate of deterioration measured by a muscle-testing score was $33.4 \%$ reduced in patients treated with Riluzole. ${ }^{81}$ After 2 years, Riviere et al. ${ }^{82}$ described that only the milder cases have less progression. ${ }^{82}$ The group of Turner et al. ${ }^{83}$ defined Riluzole as an independent prognostic factor and Brooks et al. ${ }^{84}$ found that patients treated with Riluzole stay longer in mild and moderate stage of the disease. ${ }^{83,84}$ In our study, the majority of the patients had a decrease in deterioration rate and stabilization of the disease even when not just mild cases where included (Figure 1) (Figure 1)

The ALS/Riluzole study group described that after a 12 months follow-up $71 \%$ of the patients treated with Riluzole were alive a $16 \%$ more than the control group. At 21 months after treatment $49 \%$ were alive, only $12 \%$ more than the treated group with a median survival of 17.7 months after treatment. ${ }^{81}$ These controversial results are more positive than in our study (Table 1), however they are questioned in later surveys permanently, also they do not take into account the outcome after 21 months of treatment, probably and according to other studies involving Riluzole, because the effectiveness through time is decreased.

In 2003 Traynor et al. ${ }^{85}$ described that Riluzole reduced by $23 \%$ mortality at 6 months and by $15 \%$ at 12 months in a population based registry ${ }^{85}$ however when we looked at the population-based studies that take into account the use of Riluzole like Lee et al. ${ }^{22}$ (Table 1) our patients had $14 \%$ higher survival rates in the first year, $13 \%$ after 5 years and $20 \%$ after 10 years, point out again the long-term influence of one time POCST compared to the relative peak of Riluzole in the first months that do not conferee long-term improvement even with the continuation of the drug. These facts also open the possibility of using more than one POCST to potentiate the effect.

Up to today, a number of attempts to improve Riluzole effect had been made, however remain controversial. ${ }^{86}$ At the end, Riluzole extend survival for merely a few months and only for a short period of time.$^{87}$ Furthermore, there is an extensive side effect profile in Riluzole users compared to the few temporal side effects of POCST.

\section{Limitations of the study}

The principal limitation is the design of the study that was retrospective and without control group. The second limitation is that due to different places of residence the access to a proper health personal to perform objective neurological follow-up was not possible in all patients thus we had an extensive loss of patients without objective clinical follow-up.

\section{Conclusion and future}

Regrettably, today there is no official approved treatment that changes or intensively slows ALS progression, hence the current approach is to focus mainly in symptomatology and palliation with multidisciplinary treatments. ${ }^{7,88,89}$ However, it is clearly not entirely successful. We propose POCST as a treatment that is secure, an aspect that had been already described before by other authors and confirmed by us with this study. Furthermore, we can address the effect of improving clinical outcome, stabilizing the disease and reducing mortality in a short and long-term framework with better results as any other combined or single treatment described before.

The study determined basic parameters to predict outcome of patients undergoing POCST. In this line we conclude that the more milliliters available in BM conferee higher amounts of CD34+ cells and vitality per $\mathrm{ml}$, highest vitality predict good response to treatment when it is over $80 \%$. Concerning to the cells infused we determined that more than 4 million CD34+ cells IM, high amounts of CD34+ cells infused IV and high amounts of BMP infused IM are statistically significant related to the clinical outcome and survival of the patients. We also found that the SOP infusion could add better response to treatment alone or combined with LP infusion improving the survival.

We consider information about the possible pathogenesis remarkable. The greatest limitation to treatALS is lack of understanding the causes of sporadic ALS. ${ }^{90}$ In order to support efforts of elucidating the cause we found data that supports the theory of migration and functional deficiency in bone marrow and other locations of stem cells that contributes to poor moto neuron tissue renewal.

This study set sufficient data concerning safety and efficacy of the method. ALS is a disease characterized by moto neurons loss; hence cure can only come from regeneration of such cells or by providing new cells. Chemical or drug related treatments can only try to stop the progression of the disease or support the regeneration of new cells from the existing cells. With this in mind and the data provided in several other publications, stem cells transplantation seems to be a feasile treatment for ALS. 


\section{Acknowledgements}

None.

\section{Conflict of interest}

The author declares no conflict of interest.

\section{References}

1. Rowland LP, Shneider NA. Amyotrophic Lateral Sclerosis. $N$ Engl $J$ Med. 2001;344(22):1688-1700.

2. Gordon PH. Amyotrophic lateral sclerosis:an update for 2013 clinical features, pathophysiology, management and therapeutic trials. Aging Dis. 2013;4(5):295-310.

3. Logroscino G, Traynor BJ, Hardiman O, et al. Incidence of amyotrophic lateral sclerosis in Europe. J Neurol Neurosurg Psychiatry. 2010;81(4):385-390.

4. Ravits J, Appel S, Baloh RH, et al. Deciphering amyotrophic lateral sclerosis:what phenotype, neuropathology and genetics are telling us about pathogenesis. Amyotroph Lateral Scler Front Degener. 2013;14(Suppl 1):5-18.

5. Millecamps S, Salachas F, Cazeneuve C, et al. SOD1, ANG, VAPB, TARDBP, and FUS mutations in familial amyotrophic lateral sclerosis:genotype-phenotype correlations. J Med Genet. 2010;47(8):554560 .

6. Brown RC, Lockwood AH, Sonawane BR. Neurodegenerative diseases: an overview of environmental risk factors. Environ Health Perspect. 2005;113(9):1250-1256.

7. Traynor BJ, Alexander M, Corr B, et al. Effect of a multidisciplinary amyotrophic lateral sclerosis (ALS) clinic on ALS survival:a population based study, 1996-2000. J Neurol Neurosurg Psychiatry. 2003;74(9):1258-1261.

8. Gordon PH, Corcia P, Lacomblez L, et al. Defining survival as an outcome measure in amyotrophic lateral sclerosis. Arch Neurol. 2009;66(6):758-761.

9. Qureshi M, Schoenfeld DA, Paliwal Y, et al. The natural history of ALS is changing: improved survival. Amyotroph Lateral Scler. 2009;10(56):324-331.

10. Kristensen O, Melgaard B. Motor neuron disease. Prognosis and epidemiology. Acta Neurol Scand. 1977;56(4):299-308.

11. Forsgren L, Almay BG, Holmgren G, et al. Epidemiology of motor neuron disease in northern Sweden. Acta Neurol Scand. 1983;68(1):20-29.

12. Murros K, Fogelholm R. Amyotrophic lateral sclerosis in middle-finland: an epidemiological study. Acta Neurol Scand. 1983;67(1):41-47.

13. Gubbay SS, Kahana E, Zilber N, et al. Amyotrophic lateral sclerosis. A study of its presentation and prognosis. J Neurol. 1985;232(5):295-300.

14. Yoshida S, Mulder DW, Kurland LT, et al. Follow-up study on amyotrophic lateral sclerosis in Rochester, Minn., 1925 through 1984. Neuroepidemiology. 1986;5(2):61-70.

15. Granieri E, Carreras M, Tola R, et al. Motor neuron disease in the province of Ferrara, Italy, in 1964-1982. Neurology. 1988;38(10):16041608.

16. Tysnes OB, Vollset SE, Larsen JP, et al. Prognostic factors and survival in amyotrophic lateral sclerosis. Neuroepidemiology. 1994;13(5):226235.

17. Del Aguila MA, Longstreth WT, McGuire V, et al. Prognosis in amyotrophic lateral sclerosis: a population-based study. Neurology. 2003;60(5):813-819.
18. Forbes RB, Colville S, Swingler RJ, et al. The epidemiology of amyotrophic lateral sclerosis (ALS/MND) in people aged 80 or over. Age Ageing. 2004;33(2):131-134.

19. Mandrioli J, Faglioni P, Nichelli P, et al. Amyotrophic lateral sclerosis: prognostic indicators of survival. Amyotroph Lateral Scler. 2006;7(4):211-220.

20. Chancellor AM, Slattery JM, Fraser H, et al. The prognosis of adultonset motor neuron disease: a prospective study based on the Scottish Motor Neuron Disease Register. J Neurol. 1993;240(6):339-346.

21. Gordon PH, Salachas F, Lacomblez L, et al. Predicting survival of patients with amyotrophic lateral sclerosis at presentation: a 15-year experience. Neurodegener Dis. 2013;12(2):81-90.

22. Lee CT, Chiu YW, Wang KC, et al. Riluzole and prognostic factors in amyotrophic lateral sclerosis long-term and short-term survival: a population-based study of 1149 cases in Taiwan. $J$ Epidemiol. 2013;23(1):35-40.

23. EFNS Task Force on Diagnosis and Management of Amyotrophic Lateral Sclerosis:, Andersen PM, Abrahams S, Borasio GD, et al. EFNS guidelines on the clinical management of amyotrophic lateral sclerosis (MALS) - revised report of an EFNS task force. Eur J Neurol. 2012;19(3):360-375.

24. Miller RG, Jackson CE, Kasarskis EJ, et al. Practice parameter update:the care of the patient with amyotrophic lateral sclerosis:multidisciplinary care, symptom management, and cognitive/behavioral impairment (an evidence-based review): report of the Quality Standards Subcommittee of the American Academy of Neurology. Neurology. 2009;73(15):1227-1233.

25. Clark J, Pritchard C, Sunak S, et al. Amyotrophic Lateral Sclerosis: A report on the state of research into the cause, cure, and prevention of ALS. USA: Rep MA Dept Health; 2005. p. 1-359.

26. Kumar DR, Aslinia F, Yale SH, et al. Jean-Martin Charcot: The Father of Neurology. Clin Med Res. 2011;9(1):46-49.

27. Thomson JA, Itskovitz Eldor J, Shapiro SS, et al. Embryonic stem cell lines derived from human blastocysts. Science. 1998;282(5391):11451147.

28. Appel SH, Engelhardt JI, Henkel JS, et al. Hematopoietic stem cell transplantation in patients with sporadic amyotrophic lateral sclerosis. Neurology. 2008;71(17):1326-1334.

29. Mezey E, Chandross KJ, Harta G, et al. Turning blood into brain: cells bearing neuronal antigens generated in vivo from bone marrow. Science. 2000;290(5497):1779-1782.

30. Ende N, Weinstein F, Chen R, et al. Human umbilical cord blood effect on sod mice (amyotrophic lateral sclerosis). Life Sci. 2000;67(1):53-59.

31. Garbuzova-Davis S, Willing AE, Zigova T, et al. Intravenous administration of human umbilical cord blood cells in a mouse model of amyotrophic lateral sclerosis:distribution, migration, and differentiation. $J$ Hematother Stem Cell Res. 2003;12(3):255-720.

32. Garbuzova-Davis S, Rodrigues MCO, Mirtyl S, et al. Multiple intravenous administrations of human umbilical cord blood cells benefit in a mouse model of ALS. PloS One. 2012;7(2):e31254.

33. Lunn JS, Hefferan MP, Marsala M, et al. Stem cells: comprehensive treatments for amyotrophic lateral sclerosis in conjunction with growth factor delivery. Growth Factors. 2009;27(3):133-140.

34. Xu L, Ryugo DK, Pongstaporn T, et al. Human neural stem cell grafts in the spinal cord of SOD1 transgenic rats: differentiation and structural integration into the segmental motor circuitry. J Comp Neurol. 2009;514(4):297-309. 
35. Yamanaka K, Chun SJ, Boillee S, et al. Astrocytes as determinants of disease progression in inherited amyotrophic lateral sclerosis. $\mathrm{Nat} \mathrm{Neu}$ rosci. 2008;11(3):251-253.

36. Rothstein JD, Van Kammen M, Levey AI, et al. Selective loss of glial glutamate transporter GLT-1 in amyotrophic lateral sclerosis. Ann Neurol. 1995;38(1):73-84.

37. Yamanaka K, Yamashita H. [ALS and microglia—a player for non-cellautonomous neuron death]. Brain Nerve Shinkei Kenkyū No Shinpo. 2007;59(10):1163-1170.

38. Clement AM, Nguyen MD, Roberts EA, et al. Wild-type nonneuronal cells extend survival of SOD1 mutant motor neurons in ALS mice. Science. 2003;302(5642):113-117.

39. Bruijn LI, Houseweart MK, Kato S, et al. Aggregation and motor neuron toxicity of an ALS-linked SOD1 mutant independent from wild-type SOD1. Science. 1998;281(5384):1851-1854.

40. Boillée S, Vande Velde C, Cleveland DW. ALS: a disease of motor neurons and their nonneuronal neighbors. Neuron. 2006;52(1):39-59.

41. Peljto M, Wichterle H. Programming embryonic stem cells to neuronal subtypes. Curr Opin Neurobiol. 2011;21(1):43-51.

42. Peljto M, Dasen JS, Mazzoni EO, et al. Functional diversity of ESC-derived motor neuron subtypes revealed through intraspinal transplantation. Cell Stem Cell. 2010;7(3):355-366.

43. Dimos JT, Rodolfa KT, Niakan KK, et al. Induced pluripotent stem cell generated from patients with ALS can be differentiated into motor neurons. Science. 2008;321(5893):1218-1221.

44. Wichterle H, Lieberam I, Porter JA, et al. Directed differentiation of embryonic stem cells into motor neurons. Cell. 2002;110(3):385-397.

45. Lepore AC, Rauck B, Dejea C, et al. Focal transplantation-based astrocyte replacement is neuroprotective in a model of motor neuron disease. Nat Neurosci. 2008;11(11):1294-1301.

46. Vitry S, Bertrand JY, Cumano A, et al. Primordial hematopoietic stem cells generate microglia but not myelin-forming cells in a neural environment. J Neurosci Off J Soc Neurosci. 2003;23(33):10724-10731.

47. Beers DR, Henkel JS, Xiao Q, et al. Wild-type microglia extend surviva in PU.1 knockout mice with familial amyotrophic lateral sclerosis. Proc Natl Acad Sci USA. 2006;103(43):16021-16026.

48. Suzuki M, McHugh J, Tork C, et al. GDNF secreting human neural progenitor cells protect dying motor neurons, but not their projection to muscle, in a rat model of familial ALS. PloS One. 2007;2(8):e689.

49. Park S, Kim HT, Yun S, Kim IS, Lee J, et al. Growth factor-expressing human neural progenitor cell grafts protect motor neurons but do not ameliorate motor performance and survival in ALS mice. Exp Mol Med. 2009;41(7):487-500.

50. Hwang DH, Lee HJ, Park IH, et al. Intrathecal transplantation of human neural stem cells overexpressing VEGF provide behavioral improvement, disease onset delay and survival extension in transgenic ALS mice. Gene Ther. 2009;16(10):1234-1244.

51. Suzuki M, McHugh J, Tork C, et al. Direct muscle delivery of GDNF with human mesenchymal stem cells improves motor neuron survival and function in a rat model of familial ALS. Mol Ther J Am Soc Gene Ther. 2008;16(12):2002-2010.

52. Mazzini L, Mareschi K, Ferrero I, et al. Mesenchymal stromal cell transplantation in amyotrophic lateral sclerosis: a long-term safety study. $C y$ totherapy. 2012;14(1):56-60.

53. Mazzini L, Ferrero I, Luparello V, et al. Mesenchymal stem cell transplantation in amyotrophic lateral sclerosis:A Phase I clinical trial. Exp Neurol. 2010;223(1):229-237.
54. Feldman EL, Boulis NM, Hur J, et al. Intraspinal neural stem cell transplantation in amyotrophic lateral sclerosis: phase 1 trial outcomes. Ann Neurol. 2014;75(3):363-373

55. WMA Declaration of Helsinki - Ethical Principles for Medical Research Involving Human Subjects. 18th WMA General Assembly, Finland; 2013.

56. Brooks BR, Miller RG, Swash M, et al. World Federation of Neurology Research Group on Motor Neuron Diseases. El Escorial revisited: revised criteria for the diagnosis of amyotrophic lateral sclerosis. Amyotroph Lateral Scler Mot Neuron Disord Off Publ World Fed Neurol Res Group Mot Neuron Dis. 2000;1(5):293-299.

57. Gordon PH, Miller RG, Moore DH, et al. Amyotrophic Lateral Sclerosis and other Motor Neuron Disorders. Taylor Francis Online; 2004. 5(Suppl 1):90-93.

58. Bain B. Bone marrow aspiration. J Clin Pathol. 2001;54(9):657-663.

59. Aktas M, Radke TF, Strauer BE, et al. Separation of adult bone marrow mononuclear cells using the automated closed separation system Sepax. Cytotherapy. 2008;10(2):203-211.

60. Sutherland DR, Anderson L, Keeney M, et al. The ISHAGE guidelines for $\mathrm{CD} 34+$ cell determination by flow cytometry. International Society of Hematotherapy and Graft Engineering. $J$ Hematother. 1996;5(3):213-226.

61. Kaplan E, Meier P. Nonparametric estimation from incomplete observations. J Am Stat Assoc. 1958;53(282):457-481.

62. Mehta T, Feroz A, Thakkar U, et al. Subarachnoid placement of stem cells in neurological disorders. Transplant Proc. 2008;40(4):1145-1147.

63. Lalu MM, McIntyre L, Pugliese C, et al. Safety of Cell Therapy with Mesenchymal Stromal Cells (SafeCell): A Systematic Review and Meta-Analysis of Clinical Trials. PLoS One. 2012;7(10):e47559.

64. Momin EN, Vela G, Zaidi HA, et al. The oncogenic potential of mesenchymal stem cells in the treatment of cancer:directions for future research. Curr Immunol Rev. 2010;6(2):137-148.

65. Prockop DJ, Brenner M, Fibbe WE, et al. Defining the risks of mesenchymal stromal cell therapy. Cytotherapy. 2010;12(5):576-578.

66. Prasad VK, Lucas KG, Kleiner GI, et al. Efficacy and safety of ex vivo cultured adult human mesenchymal stem cells (ProchymalTM) in pediatric patients with severe refractory acute graft-versus-host disease in a compassionate use study. Biol Blood Marrow Transplant 2011;17(4):534-541.

67. Müller I, Kordowich S, Holzwarth C, et al. Application of multipotent mesenchymal stromal cells in pediatric patients following allogeneic stem cell transplantation. Blood Cells Mol Dis. 2008;40(1):25-32.

68. Prabhakar S, Rajan R, Sharma R, et al. Autologous bone marrow-derived stem cells in amyotrophic lateral sclerosis: A pilot study. Neurol India. 2012;60(5):465-469.

69. Mazzini L, Mareschi K, Ferrero I, et al. Autologous mesenchymal stem cells: clinical applications in amyotrophic lateral sclerosis. Neurol Res. 2006;28(5):523-526.

70. Blanquer M, Moraleda JM, Iniesta F, et al. Neurotrophic bone marrow cellular nests prevent spinal motoneuron degeneration in amyotrophic lateral sclerosis patients: a pilot safety study. Stem Cells. 2012;30(6):1277-1285.

71. Karussis D, Karageorgiou C, Vaknin-Dembinsky A, et al. Safety and immunological effects of mesenchymal stem cell transplantation in patients with multiple sclerosis and amyotrophic lateral sclerosis. Arch Neurol. 2010;67(10):1187-1194 
72. Deda $\mathrm{H}$, Inci $\mathrm{MC}$, Kürekçi $\mathrm{AE}$, et al. Treatment of amyotrophic lateral sclerosis patients by autologous bone marrow-derived hematopoietic stem cell transplantation:a 1-year follow-up. Cytotherapy. 2009;11(1):18-25.

73. Salemi G, Fierro B, Arcara A, et al. Amyotrophic lateral sclerosis in palermo, Italy:an epidemiological study. Ital J Neurol Sci. 1989;10(5):505509.

74. Chiò A, Calvo A, Bovio G, et al. Amyotrophic lateral sclerosis outcome measures and the role of albumin and creatinine: a population-based study. JAMA Neurol. 2014;71(9):1134-1142.

75. Jensen GS, Drapeau C. The use of in situ bone marrow stem cells for the treatment of various degenerative diseases. Med Hypotheses. 2002;59(4):422-428.

76. Koh SH, Baik W, Noh MY, et al. The functional deficiency of bone marrow mesenchymal stromal cells in ALS patients is proportional to disease progression rate. Exp Neurol. 2012;233(1):472-480.

77. Mazzini L, Mareschi K, Ferrero I, et al. Stem cell treatment in Amyotrophic Lateral Sclerosis. J Neurol Sci. 2008;265(1-2):78-83.

78. Chiò A, Calvo A, Moglia C, et al. Phenotypic heterogeneity of amyotrophic lateral sclerosis: a population based study. J Neurol Neurosurg Psychiatry. 2011;82(7):740-746.

79. Pupillo E, Messina P, Logroscino G, et al. Long-term survival in amyotrophic lateral sclerosis: a population-based study. Ann Neurol. 2014;75(2):287-297.

80. Sorenson EJ, Stalker AP, Kurland LT, et al. Amyotrophic lateral sclerosis in Olmsted County, Minnesota, 1925 to 1998. Neurology. 2002;59(2):280-282.
81. Bensimon G, Lacomblez L, Meininger V. A controlled trial of riluzole in amyotrophic lateral sclerosis. $N$ Engl J Med. 1994;330(9):585-591.

82. Riviere M, Meininger V, Zeisser P, et al. An analysis of extended survival in patients with amyotrophic lateral sclerosis treated with riluzole. Arch Neurol. 1998;55(4):526-528.

83. Turner MR, Bakker M, Sham P, et al. Prognostic modelling of therapeutic interventions in amyotrophic lateral sclerosis. Amyotroph Lateral Scler Mot Neuron Disord. 2002;3(1):15-21.

84. Brooks BR. What are the implications of early diagnosis? Maintaining optimal health as long as possible. Neurology. 1999;53(8 Suppl 5):S43S45

85. Traynor BJ, Alexander M, Corr B, et al. An outcome study of riluzole in amyotrophic lateral sclerosis - a population-based study in Ireland, 1996-2000. J Neurol. 2003;250(4):473-479.

86. Ludolph AC, Jesse S. Evidence-based drug treatment in amyotrophic lateral sclerosis and upcoming clinical trials. Ther Adv Neurol Disord. 2009;2(5):319-326.

87. Borasio GD, Miller RG. Clinical characteristics and management of ALS. Semin Neurol. 2001;21(2):155-166.

88. Gordon PH, Mitsumoto H. Chapter 20 Symptomatic therapy and palliative aspects of clinical care. Handb Clin Neurol. 2007;82:389-424.

89. Corcia P, Meininger V. Management of amyotrophic lateral sclerosis. Drugs. 2008;68(8):1037-1048.

90. Maragakis NJ. Stem cells and the ALS neurologist. Amyotroph Lateral Scler. 2010;11(5):417-423. 